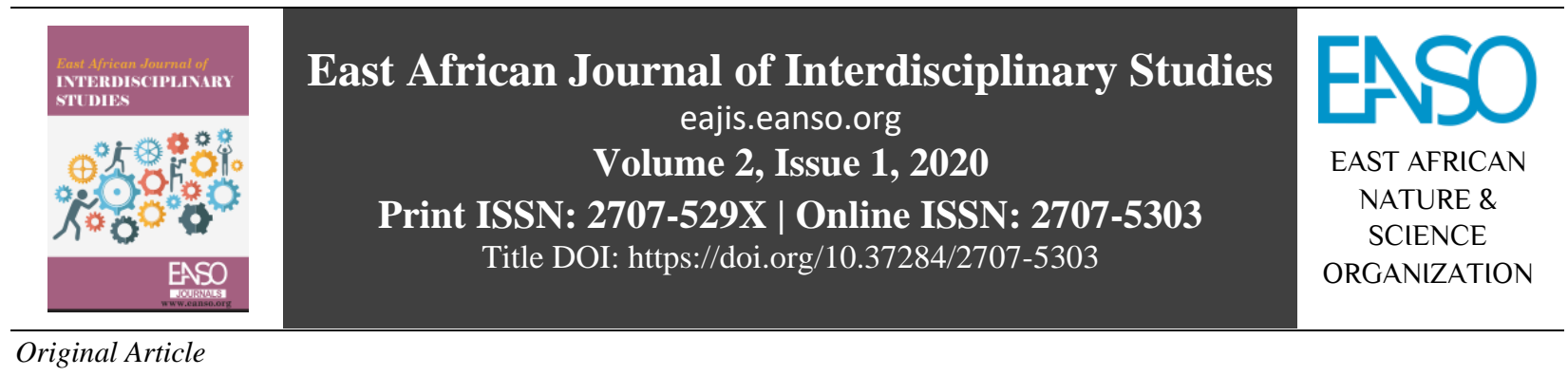

\title{
Theatre as an Agent of Change: Mobilising Against Marijuana Addiction in Tombia Ekpetiama Community in Bayelsa State
}

\author{
Ebinepere Zibokere ${ }^{1}$ \& Ekiyokere Ekiye 2* $^{*}$ \\ ${ }^{1}$ Department of Theatre Arts, Niger Delta University, Nigeria; Email: ebipretti@gmail.com. \\ ${ }^{2}$ Department of English and Communication Studies, Federal University Otuoke, Nigeria. \\ * Author for Correspondence Email: ekiblack2@gmail.com
}

\section{Article DOI: https://doi.org/10.37284/eajis.2.1.155}

\section{Date Published: ABSTRACT}

18 May 2020 This paper posits community theatre as an agent of change and argues that community theatre possesses the technicalities to bring awareness to the members of a

Keywords: community to the social and cultural issues affecting them via their exploration in drama or performance, thereby causing changes in their mindset, action and

Community socialisation patterns. With a focus on marijuana addiction amongst the youths in Theatre, Tombia, Ekpetiama, the paper critically analyses the effectiveness of community Marijuana, theatre in mobilising, sensitising, entertaining and educating the community members Addiction, on the dangers of drug abuse. Marijuana addiction is a challenge worldwide and Mobilisation, theatre practitioners have engaged several community theatre projects in order to Change. sensitise addicts on the need to do away with drugs. This work used focus group interactions, participant observation and in-depth interviews methods to record the opinions of the people of Tombia community on issues of concern evolving from marijuana abuse. Adopting performance analysis schemata, the responses recorded were structured as thematic strands analysed and interpreted in line with the research objectives. Findings showed that community theatre is a viable avenue within which Tombia, Ekpetiama community became aware and knowledgeable about the social challenges of marijuana addiction. This in turn influenced the resolve of the youths to change by shunning marijuana smoking while the community elders were prompted to put progressive local measures in place in order to checkmate the youths and boost practices that strengthen development. Therefore, it was concluded that, community theatre is indeed an ideal agent for the mobilisation of people at the grassroots level as it encourages village or community participation to open room for them to assess their problems and proffer solutions via the implementation of meaningful changes that aid community development. The study contributes to the understanding of community theatre and exposes its efficacy, as an additional strategy; to fight against drug abuse in communities in Nigeria. 


\section{APA CITATION}

Zibokere, E., \& Ekiye, E. (2020). Theatre as an Agent of Change: Mobilising Against Marijuana Addiction in Tombia Ekpetiama Community in Bayelsa State. East African Journal of Interdisciplinary Studies, 2(1), 1-11. https://doi.org/10.37284/eajis.2.1.153

\section{CHICAGO CITATION}

Zibokere, Ebinepere, and Ekiyokere Ekiye. 2020. "Theatre As an Agent of Change: Mobilising Against Marijuana Addiction in Tombia Ekpetiama Community in Bayelsa State". East African Journal of Interdisciplinary Studies 2 (1), 1-11. https://doi.org/10.37284/eajis.2.1.153.

\section{HARVARD CITATION}

Zibokere, E. and Ekiye, E. (2020) "Theatre as an Agent of Change: Mobilising Against Marijuana Addiction in Tombia Ekpetiama Community in Bayelsa State", East African Journal of Interdisciplinary Studies, 2(1), pp. 1-11. doi: 10.37284/eajis.2.1.153.

\section{IEEE CITATION}

E. Zibokere and E. Ekiye, "Theatre as an Agent of Change: Mobilising Against Marijuana Addiction in Tombia Ekpetiama Community in Bayelsa State", EAJIS, vol. 2, no. 1, pp. 1-11, May 2020.

\section{MLA CITATION}

Zibokere, E., and E. Ekiye. "Theatre As an Agent of Change: Mobilising Against Marijuana Addiction in Tombia Ekpetiama Community in Bayelsa State". East African Journal of Interdisciplinary Studies, Vol. 2, no. 1, May 2020, pp. 1-11, doi:10.37284/eajis.2.1.153.

\section{INTRODUCTION}

When the word "theatre" is mentioned, what seems to resonate in the minds of most people is the conventional theatre and not community theatre, which is what is referred to in this paper. Community theatre refers to the theatre in the community. It is "a type of theatrical style which stresses 'participation', 'dialogue', 'critical consciousness' etc” (Iyorwuese, 1990, p. 5). Community theatre is performed for purposes of development, sensitisation and encouragement of the individuals in rural settings; this is only achieved through the plays acted out to represent or capture the experiences and concerns of the community, thereby changing the manner individuals behave, think and relate. In this paper, theatre is used as an agent of change against marijuana addiction in Tombia, Ekpetiama community of Bayelsa State. Hence, theatre takes the form of drama performed, involving the people's participation to open an avenue for change in the area under study. What then is drama?

Drama is "the art of expressing ideas about life so that they may be interpreted by actors before an audience assembled to hear words and witness action" (Agoro, 1994). In order to boost interaction between the theatre artists and the members of any community, the community theatre practitioner adopts the language and local art forms of the target individuals. This will improve the chances of the expected change (for instance, sensitising youths against marijuana addiction) he or she hopes to effect in the lives of the members of the said community.

\section{Research Problem}

Marijuana addiction is not specific to a particular country, race, and community or state rather, it is a global problem. Investigations by the National Institute of Mental Health, United Kingdom, revealed that the individuals who took strong doses of marijuana showed 'psychotic reactions'. Habitual users of marijuana ultimately experience a failing memory and some difficulty in concentrating (Phillips, 1979). Marijuana, also known as Cannabis Sativa, is a hallucinogenic drug retrieved from the hemp plant that is grown in temperate and tropical climates around the globe. Although this herb has been observed to be effective medically in the treatment of nervous exhaustion and pain in some parts of Asia, Israel, America, Nigeria etc., the use of marijuana was banned subsequently in order to make it difficult for individuals to get access to addictive drugs. However, it appears that the efforts made by governmental and non- governmental organisations -for example, National Drug Law Enforcement Agency and World Health Organization (WHO) 
among other national and international agencies to reduce the rate of marijuana addiction in Nigeria, Tombia community inclusive, have not had much impact on the youth (Akanle, Adesina, \& Adebayo, 2015).

Tombia is one of the communities in Ekpetiama; it has been in existence for more than 100 years. The community has been governed by the 'Amananaowei' meaning 'he who is the owner of the 'town'. The major occupations of the people are fishing and farming and this happens to be their major source of livelihood. The people of Tombia are viewed as accommodating and respectful of visitors. Tombia has been a peaceful community until recently when the intake of marijuana and its abuse by the youth in the community was observed. Marijuana addiction is now a major problem in the community. This paper, therefore, intends to use community theatre as a strategy for change against the drug abuse, specifically marijuana addiction in the aforementioned community and having not seen much work on this topic in Bayelsa state, it becomes necessary to carry out this research.

\section{THE CONCEPT OF COMMUNITY THEATRE}

Theatre does not operate in isolation, but it was birthed out of "... the collectively motivated performance of massive societies. And its function has no value in isolation from societies" (Diang'a \& Kebaya, 2016, p. 2). Theatre was first interpreted from an archaic lens as 'Art for Art's sake'; an assumption which tends to isolate its importance from communities or societies. Subsequently, there was a shift in perspectives from theatre being primarily for entertainment, to other interpretations about the concept of theatre. They are Augusto Boal's Theatre of the Oppressed (1979), Bertolt Brecht's Epic Theatre (1874), Grotowsky's Poor Theatre (1968) (Diang' a \& Kebaya, 2016). All three (3) perspectives are similar in that they agree on the unique correspondence between theatre and society. Kershaw (1992) supports these perspectives when he advises that "...we must move beyond formalist analysis -which treats theatre as if it were independent of its social and political environment- and consider performance as a cultural construct and as a means of cultural production" (p. 5). Hence, community theatre, as a concept, is a major aspect of transformation that includes cultural discourse.

Diang' a and Kebaya (2016) notes that Kuftenic (2001) observes that community theatre has its origin tied to the freedoms struggles of the 1960s and 1970s when it was used to convince people to join the cause; thus, community theatre is 'grassroots' or 'community based' theatre. It is further added that community theatre has some similarities with drama and theatre in education. These are unpopular modes of theatre that take various patterns.

It is pertinent to mention that in Africa, Nigeria inclusive, there appears to be a direct nexus between Community Theatre and Theatre for Development. Oftentimes, both forms of theatre are regarded as the same. However, in the present research, community theatre is viewed as an agent for change, development, and education against marijuana addiction in a specific community hinged on participatory methodologies in the form of drama. This seems to correspond with Diang'a and Kebaya's (2016) standpoint that "Community theatre should be viewed as the drama of, by, and for a community that appropriates artistic practices for its own desires, which are not always in accordance with those of mainstream Applied Theatre practices" (p. 3). Their interpretation of community theatre agrees with Cohen-Cruz's (1999) view when he mentions that "community based-theatre, a popular mode allied with identity politics and targeting under-represented groups in the quest for the collective expression" (p. 115). Hence, it empowers the less dominant individuals to face the existing patterns of symbols, traditions and values in their community.

\section{Evaluation of Case Studies of Community Theatre Projects for Social Mobilization}

The key model for community theatre globally is the use of indigenous materials and local patterns of communication in order to evaluate and effect a change against some vice or another. Community theatre calls attention to and/or unravel the issues plaguing a community (Prentki \& Preston 2009). As such, the community members are the 'drivers' of the creative input and create grassroots reflection and performance in a shared collective form of 
sociocultural empowerment (Van Erven, 2001). Diang'a \& Kebaya (2016) support that:

"Community theatre gives first-hand opportunities to community members to participate in the creation and performance of community dramas. The direct participation of community members in this dramaturgical process has a couple of advantages."

It enables one-mindedness in the performance such that it creates "...a sense of ownership in the participant's own cultural heritage" (Kellin 2001, p. 155). For instance, The Leazda Batanani Model in Botswana which translates to "community awakening" (the program occurred in the Bokalala District from 1974 to 1977) employs community theatre to critically assess their socio-economic situation and after adequate documentation of findings, attempts to proffer solutions on what should be obtainable were made (Kidd \& Martin, 1982). Here, the participants concentrated on predetermined issues in agriculture, health, selfreliance, sanitation, social relevance etc. all problems at the community or village level. In this model, the dramas were readily made by external parties after their research; they were only brought to the villages for performance as finished products. This project had several shortcomings. First, it undermined the importance of the members of the community in the key stages of data analysis and the making of the drama. Second, the lack of village/community participation in the crucial stages aforementioned robbed the model of the momentum to include the community members to efficiently mobilise for follow-up action. Lastly, the conclusions drawn from the drama appeared to be imposed on the people as they were just an audience (passive and uninvolved) to their predicament as interpreted and acted out by outsiders.

The Sierra-Leone Segbeme Model on the other hand, since its introduction in the 1970s via the pioneering work of the Corporative American Relief Everywhere (CARE) has upgraded to the Botswana model of applying theatre as a means of passing down development information to the communities via the activities of INSTADEX (Institute of Adult Education and Extra-Mural Studies) to become more participatory in its approach to community theatre (Malamah-Thomas,
1987). The participants from Liberia, Sierra-Leone and Nigeria were put into groups of fourteen and dispatched to the remote the villages, Fzoola and Magbema, to live and research on the problems of the youth. They were also tasked with observing their indigenous communication materials as traditional performance idioms and these were included in dramas that addressed the problems and provided solutions. The participant ensured that the villagers were sufficiently involved in the key stages and this gave room for effective rapport between them; thereby boosting the trust of the villagers and the non-village participants in the process of community theatre. Unlike the Leazda Batanani Model in Botswana, this model flourished because of the active participation of the villagers at every stage.

As in the Sierra-Leone Segbeme Model, the Zaria Samaru Model of 1980 in Nigeria used community theatre for social mobilisation. This model also has been innovative in its application of community theatre, even though the Ahmadu Bello University (ABU) in Zaria had initially used the Botswana model, which was abandoned after Soba project in order to discourage passive participation of the villagers and encourage their active involvement in creating plays. As such, subsequent community theatre projects have progressively included the local communities in Zaria to put community theatre associations together and incorporate the traditional cultural forms in its model. Again, like the Sierra-Leone model, the Zaria model succeeded because the members of the local communities were engaged at every stage or process to actualise the project. This also enabled the theatre practitioners to not only assess their challenges adequately, but it created room to proffer meaningful solutions to the issues observed and follow-up (Kafewo, 2004, p. 56).

Unlike the Zaria model, Usen (2012) mentions that the Soba Projects which began with Steve Abah in March 1977, recorded little success because of the passive community theatre approach of the theatre practitioners. Soba is a community situated along the Zaria-Jos road and the plays (known as 'Wasan Manoma' meaning play for farmers) for the project were on the issues taunting farmers during the Operation Feed the Nation (OFN) campaign in the Obasanjo regime. While one play focused on how 
fertilisers meant for farmers were being swindled, the other play looks into the issue of farmers' cooperatives, the third play addressed the problem of youth migration from rural to urban cities and the fourth play criticised the sweet promises of politicians that never saw the light of day. However, the Soba projects which were carried in the four target communities where the plays were acted out did not succeed because the villagers were only involved in the performance and post-performance discussions and not the preparatory or planning or research stages, which were done by the student of Ahmadu Bello University, Zaria.

The Samaru Project, first done in 1980, discussed problems like unemployment, drug abuse and other vices plaguing the community. The project named as 'Wayar da Kaijuna' meaning 'mutual enlightenment' has since become an annual project, but it has not progressed as far as the community project (Oga \& Micheal, 1982). The reason being that there has not been much continuity and followup as the villagers in the community of focus were not involved in the project. The project appears to have adopted the migrant method as it was limited to outside or foreign participation without due consideration for the challenges of the communities.

The uniqueness in all the projects evaluated is the fact that they were all used community theatre for mobilisation against the distinct vices observed in their various target communities. However, most of these projects or models as the Leazda Batanani Model in Botswana, the Soba Projects and the Samaru Project were not successful because the theatre practitioners failed to recognise the importance of indigenous participation in the communities under study, others like the Zaria model and the Sierra-Leone Segbeme Model recorded maximum success. Wiley and Feiner (2001) emphasise that the end goal of cultural or local participation in community theatre projects is "to increase opportunities for marginalised and oppressed groups to represent themselves and the world around them as a means of asserting their own identity and achieving "cultural, social, economic, and political equity" (p. 122). It is against this backdrop that current research adopts the Zaria and Sierra-Leone Segbeme Models that encourage local participation in both the structuring of community theatre projects and providing solutions to the issues of marijuana addiction affecting them in Tombia, Ekpetiama community.

\section{Marijuana Addiction in Nigeria}

The smoking of marijuana is not only viewed as a youth phenomenon, but its use is observed to be high in the youthful years and common among illiterates and the low social class respectively (Abiodun \& Afolayan, 2007; Shehu \& Idris, 2008). Several researchers (Odekunle, 1979; Alemika, 1998) comment that while countless marijuana farmlands have been destroyed plus several arrests and prosecution of marijuana abusers, reliable evidence of any accompanying decrease in marijuana addiction in Nigeria has not been recorded. Others like Anthony et al. (1997), Johnston et al., 2005 and Bell et al., 1997 have pointed out the need for further study that deals with the problems surrounding marijuana addiction and criminalisation. Nigeria is the eighth highest consumer of marijuana in the world (NBF News, 2010). Of the total 2,827, 862 recorded arrests comprising other types of hard drugs in 1990-2009, 2,794,733 cases were Marijuana related. The National Drug Law Enforcement Agency (NDLEA) (1997; 2002) confirms that marijuana (also known as Cannabis) makes up about 80 per cent of substance abuse, sale and use in Nigeria.

The aim of this study is to sensitise, educate and inform the youth in Nigeria about the dangers of marijuana addiction using community theatre. The main objectives of this research are to expose and understand youth marijuana addiction by going contextual relative to the youths in Tombia, Ekpetiama community in Bayelsa state. Furthermore, it will expand the knowledge base on Marijuana addiction particularly with the number of current researches that confirm the implications of abuse among the youth, who are subject to health issues from the increased intake of Cannabis (Resnick et al., 1997). Studies (Resnick et al, 1997, Hansen \& Chen, 2007) have shown that marijuana intake negatively affects those youths whose brains are in the developmental stage. The negative social effects of marijuana addiction among the youths have resulted in the restriction of the recreational application of marijuana usage among individuals within the age bracket of 21 years in countries like 
the USA and Nigeria. This article identifies youths involved in marijuana intake; investigates how they got involved in marijuana usage; examines their stages of addiction, and investigates the social domains (that's Tombia, Ekpetiama community in Bayelsa state) of marijuana. This study will serve as a resource material to students for research and contribute toward marijuana research and scholarship in Nigeria, specifically with regards to the effects of illegal marijuana consumption among the youths that have resulted to increased health challenges. Finally, the study will be beneficial to prospective community theatre practitioners who wish to conduct similar projects because marijuana addiction is not limited to Tombia, Ekpetiama community alone.

\section{METHODOLOGY}

The qualitative research approach was adopted in this paper. Qualitative research is research seeks to understand a phenomenon or object under study via exploration without statistical or quantifying procedures and acknowledging that such phenomenon or object could change based on the manner in which it is viewed and interrogated (Cobin \& Strauss, 2007). Qualitative research is employed to study past and present experiences of a people, performances, and sociocultural concerns. Also, the conclusions reached in this study have enabled us to confirm the efficacy of community theatre as an agent for change that has positively impacted the lives of the youths in Tombia, Ekpetiama community. Hence, the application and effectiveness of community theatre as the framework of this work determined the approach chosen. In line with McMillan and Schumacher (1993), this research work interprets reality as interactive, multidimensional and as the common social experiences that are described by people of Tombia. This is in coherence with the idea that meaning and knowledge cannot be created without taking the contexts of occurrence into cognisance. This work investigated the use of community theatre for mobilisation against marijuana addiction among the youth in Tombia as an interactive and common social experience in Ekpetiama community.

\section{Methods of Data Collection}

The primary data for this paper were gathered using different methods as in-depth interviews, focus group interactions and participant observation.

Community theatre has a journalistic approach to data collection. Instead of requiring the respondents to study questionnaires and filling them out, the researchers asked the questions following a semistructured interview guide and recorded the responses of the respondents using an audio recorder and a jotter. Hansen et al. (1998) support that interview guides serve as "manual to work from and follow." In-depth interviews create room for the interviewees to relax and respond to the questions asked without restrictions and the researchers were able to probe deeper into issues based on their responses while jotting down important observations made during the sessions.

The purpose of focus group discussions in this study was to gather information about the perception of the individuals on a particular issue of concern, which is the problem of marijuana addiction. This study used focus groups to collect data about marijuana addiction and the effectiveness of community theatre in the form of drama from selected members of Tombia, Ekpetiama community using open-ended questions as interaction guides. The researchers acted as moderators and they assisted the participants by guiding them as they expressed their viewpoints. During our interactions, we studied and observed if the drama about marijuana addiction acted out on stage, with their full participation was understood and the intended message received by the youth in Tombia, Ekpetiama community. Thus, we wanted to know how the members of Tombia, Ekpetiama community made "sense of play watched through conversation and interaction with each other" (Hansel et al., 1998). These focus group interactions enabled the researchers to make necessary observations as well as to retrieve authentic information from the community members about their receptiveness of live drama. The interactions also helped in building strong bonds between the participants and the researcher and as a result, we could assess the extent of impact community theatre in the form of drama had on them. 
According to Hansel et al. (1998), "participant observation can be one of the most exciting, challenging and potentially rewarding of all mass communication research methods." while the researchers actively participated in theatre activities like acting, singing, dancing, etc., other theatre professionals were able to observe the youths in Tombia, Ekpetiama community who watched as well as those who performed on stage. We observed their discussions after the drama had ended. This method entailed that we be part of community theatre and as such, we were able to initiate rapport with the participants, build trust and this fostered the dissemination of unbiased information from them.

\section{Data Analysis}

The data from the group discussions and interviews were recorded using a tape recorder and subsequently transcribed. The sorted data was structured into several themes and categorised for analysis. Thematic content analysis was used to analyse the study's findings. Bernard and Ryan (2010) explain that thematic analysis does not limit itself to just word or phrase numeration but its emphasis is placed on the identification and description of explicit and implicit notions (that's, themes) in the data. This paper focuses on the effectiveness of community theatre as an agent for change against marijuana addiction amongst the youths in Tombia, Ekpetiama community, which was achieved via their attitudes, experiences and viewpoints about the drama or performance they participated in and watched collectively and individually. Then, engaging systematic thematic content analysis, the participants' responses were itemised into themes and analysed extensively in line with our objectives. Finally, the information recorded from the data analysis was put together into an organised qualitative narrative.

\section{INTERPRETATION AND DISCUSSION OF FINDINGS}

The community theatre performance in Tombia, Ekpetiama drew the attention of a lot of people in the community. Community members of all agesyoung, old, men, women and youth- participated actively in the pre-performance and postperformance discussions. The issues dealt with in the drama centred on marijuana addiction which plagued the youths in the community and the performance was made lively by the laughter and time to time comments from the audience. The community theatre performance in Tombia was done using the popular participatory approach from the actors and audience alike. As such, when the determinants affecting change in the community were exposed and highlighted by the community theatre performance, efforts were immediately made to tackle such issues in the drama with regards to the collective experiences of members of the community, thereby boosting their resolve to take up measures that cause change. Such issues as cultism, developmental issues from youth restiveness, mental relapse, etc. resulting from marijuana intake and addiction were pointed out in the performance and post-performance interactions, which created the undertone for discussion on personal assessment or evaluation. The drama performed was able to arouse the participants' responses with perlocutionary effectiveness that caused changes in the viewpoints and mind-sets of the youth regarding marijuana intake/addiction in the community.

Findings from the community theatre drama revealed an adequate understanding of the issues from marijuana addiction plaguing the youths. The performance depended on the adoption of indigenous language materials like the native proverbs, native adages, figurative expressions and several funny but clever vernacular speech styles. The predetermined information was passed on to the audience without difficulty. This aroused a feeling of shared insight about the issues that make up invisible notions for change disturbing the community to concrete, readily comprehensible and actual notions or ideas that the people of Tombia, Ekpetiama could relate with. As such, when the issues springing from marijuana intake and addiction ensued in the post-drama interactions, without any threat of castigation, the participants (both spectators and actors) debated on them lengthily. The major questions that we sought to answer via the debates include: what is the opinion of the audience about marijuana intake/addiction? What are the dangers of marijuana addiction and has the community been affected by them? What measures can be put in place to eradicate marijuana abuse by the youths in 
Tombia, Ekpetiama community? Irrespective of the heated debates, the participants agreed that peer pressure, cultism, inferiority complex, militancy and poverty were major contributory factors to the prevalence of marijuana addiction observed among the youths in the community. They reiterated that these vices have led to insecurity in the town and consequently, the underdevelopment of their community.

One of the participants, a chief security officer of the community, interviewed after the postperformance expressed gratitude because he believed that youths, have been sensitised against marijuana addiction because they also had a part to play in the development of the youths. The village heads confirmed that the drama served as an eyeopener to marijuana addicts and to the non-smokers thinking of getting involved in the act. They mentioned that a ban would be placed on the sale of marijuana in the community and any youth found smoking the hallucinogenic drug would be severely punished. The women of the community on the other hand, added that it was necessary to show affection to those who are already addicts as this added measure would go a long way to discourage the habit. We witnessed a very important effect of the drama in the life of one of the spectators, Tari Gbele. At the end of the performance, he openly told us that he hadn't realised that smoking marijuana was responsible for his hostility toward friend and family. He decided to stop smoking and he resolved to return to school. As Johansson (2011) points out, this spectator took on his double role as a theatrical witness and a social player in the communal event. The community head, the Chief, immediately placed him on a scholarship. Both the children and youth of Tombia community came to a general census that they would to follow the steps of Tari Gbele and shun any form of drug abuse.

The members of the community agreed that Tombia, Ekpetiama needed to evolve and for this to become a reality, it was necessary for every one of them to collectively fight against the existing problems of marijuana addiction, cultism and other vices that prevent meaningful development and employment of the youths. This finding corresponded with Mengesteab (2006) when he emphasised that this awareness is what makes community theatre successful because it is a participatory theatre that allows the individuals to engage the issues affecting their lives in performance via the application of their native artistic expressions as proverbs, songs, native norms and cultures, mimes, etc. that incite critical dialogue within them that promote development or change.

After six (6) months, the researchers adopted the non-formal observation method to evaluate the success of the community theatre project in Tombia. The non-formal method entails being casual, engages informal greeting styles and conversations to get information about the impact of the community theatre project carried out in any town, village or community. The researchers interacted with the village head, the secretary of the community, the woman leader, the Tombia community development chairman, and the chief security officer about the efficacy of the project in the lives of the youths and the community at large. There was a consensus in their response that the Tombia, Ekpetiama community had been experiencing peace since the community theatre project. They also mentioned that laws had been passed that ban the smoking of marijuana among the youths and there were no more cases of harassment of villagers and strangers by the youths in the community.

The chief security officer, Mr. Johnbull, emphasised that he had ensured that the youths were involved in enacting the laws and they still mobilised in enforcing them. When the researchers came into contact with Mr. Tari Gbele, it was evident that he was a changed person. His appearance had improved and he testified that the community theatre performance had changed him for good. The youth leader of the community, $\mathrm{Mr}$ Preye, stated he had observed Mr. Tari and the other youths in the community since the community theatre project, and he can confidently say that youth stealing and violence has reduced. He also confirmed that Mr Tari who was a heavy marijuana addict had desisted from the act and generally, the smoking of marijuana in the community had reduced greatly. The parents of the marijuana 
addicts in the community also corroborated these reports. With these visitations, the researchers were able to evaluate that the Tombia community project and we found out that it was successful as an agent of change in the lives of the youths in the community.

\section{CONCLUSION}

This paper looked into the effectiveness of community theatre as an agent or strategy for effecting change in the mind sets and lives of the youths against marijuana consumption and addiction in Tombia, Ekpetiama community, Bayelsa state. In our discussion, we have been able to establish community theatre as drama or performance that congregates distinct groups in a community so as to enable them to debate or dialogue on the problems they are plagued with. Our findings also revealed that community theatre is structured to keep abreast with the local state of affairs in communities, villages or towns. In the case of our target community, community theatre explored the social vices of marijuana addiction as witnessed in the performance. By acting out real concerns and breaking the silence on dangers of drug abuse as cultism, robbery, insecurity etc. that do not corroborate with the desires of the people of Tombia, the community theatre project has played the important function of enlightening, sensitising and mobilising the youths as well as the elders against marijuana addiction; thereby promoting collective and individual consciousness to effect a change in their lives. Based on the foregoing, we conclude that community theatre is indeed an ideal agent for the mobilisation of people at the grassroots level as it encourages village or community participation to open room for them to assess their problems and proffer solutions via the implementation of meaningful changes that aid community development.

\section{REFERNCES}

Abiodun, P. B. \& Afolayan, A. M. (2007). Pattern of marijuana use among male university students: A case study. Journal of Medical Sciences, 7, 1068-1072.
Agoro, SNA (1994). Drama and Theatre Education. Ibadan, Caltop Publication Limited Nigeria.

Akanle, O., Adesina, J. O., \& Adebayo, O. L. (2015). Marijuana smoking among young institution of higher learning students in Nigeria. Acta Criminologica: African Journal of Criminology \& Victimology, 2015(Special Edition 3), 114-130.

Alemika, E. E. O. (1998). Narcotic drug control in Nigeria. Ibadan: Development Policy Centre.

Anthony, J. C., Warner, L. A., \& Kessler, R. C. (1997). Comparative epidemiology of dependence on tobacco, alcohol, controlled substances, and inhalants: basic findings from the National Comorbidity Survey. Experimental and Clinical Psychopharmacology, 2, 244-268.

Bell, R., Wechsler, H. \& Johnston, L. (1997). Correlates of college student marijuana use: Results of an US National Survey. Department of Health and Social Behavior, 92(5), 571-581.

Bernard, H. R., \& Ryan, G. W. (2010). Analysing qualitative data: Systematic approaches. Los Angeles, CA: Sage.

Cohen-Cruz, J. (1999). Practice and Policy in Theatre for Development. In Banham, M., Gibbs, J. and Osofisan, F. (eds.), African Theatre in Development. Oxford: James Curey.

Corbin, J. \& Strauss, A. (2007). Basics of Qualitative Research: Techniques and Procedures for Developing Grounded Theory (3rd edition). London: SAGE Publications.

Diang' a, R., \& Kebaya, C. (2016). Community theatre and development practices in Nyanza Region, Kenya. Creative Artist: A Journal of Theatre and Media Studies, 10(1), 1-24.

Hansen, A., Cottle, S., Negrine, R., \& Newbold, C. (1998). Mass communication research methods. NYU Press.

Hansen, M. D., \& Chen, E. (2007). Socioeconomic status and health behaviours in adolescence: a 
review of the literature. Journal of behavioural medicine, 30(3), 263.

Iyorwuese, H. (1990). The Practice of Community Theatre in Nigeria. Lagos, Lobi Consortium Limited.

Johansson, O. (2011). Community Theatre and AIDS. London: Palgrave MacMillan.

Johnston, L. D., O'Malley, P. M., Bachman, J. G., \& Schulenberg, J. E. (2005). Monitoring the Future: National Survey Results on Drug Use, 1975-2004. Volume II: College Students \& Adults Ages 19-45, 2004. Washington, DC: National Institutes of Health.

Kafewo, S. A. (2004). "Case Studies of Community Theatre Practices". In JenkeriOkwori Z. (ed.) Community Theatre: An Introductory Coursebook. Zaria: Tamaza Publishing Co. Ltd., $42-60$.

Kershaw, B. (1992). The Politics of Performance: Radical Theatre as Cultural Intervention. London: Routledge, a division of Chapman and Hall Inc.

Kidd, R. \& Martin, B. (1982). Popular Theatre and Non-Formal Education in Botswana: A Critique of Pseudo-Participatory Popular Education. Toronto: The Participatory Research Group.

Malamah-Thomas, D.H. (1987). Theatre Development in Sierra Leone: A study of Care's Project Learn. Africa Media Review, 1(3).

McMillan, J. H. \& Schumacher, S. (1993). Research in Education: A conceptual understanding. New York: HarperCollins.

Mengesteab, M. (2006). Community Theatre as Cultural Intervention: The case of the Samre Community Theatre Project on Evil-Eye Organised by the Tigray Arts School. Doctoral dissertation. Addis Ababa University.

National Drug Law Enforcement Agency. (1997). Drug data collection and research. Lagos: Drug Demand Reduction Unit, National Drug Law Enforcement Agency.
National Institute on Drug Abuse. (2002). Marijuana abuse. Research Report Series. Rockville: National Institute on Drug Abuse.

NBF News. (2010, Nov 22). 22 Percent of Nigerians smoke marijuana. Retrieved on April 1420202 from The Nigerian Voice, available at:

http://www.thenigerianvoice.com/nvnews/389 37/1/22-percent-of-nigerians-smokemarijuana.html.

Odekunle, F. (1979). Criminological research and police effectiveness. Zaria: Department of Sociology, Ahmadu Bello University, Zaria.

Oga, SA \& Micheal, E. (1982). The Samaru Projects: Street Theatre in Northern Nigeria. Theatre Research International, 7(3), 222-234.

Phillips, R. S. (Ed.). (1979). Funk \& Wagnalls New Encyclopedia. Funk \& Wagnals.

Prentki, T. \& Preston, S. (Eds). (2009). The Applied Theatre Reader. New York: Routledge.

Resnick, M. D., Bearman, P. S., Blum, R. W., Bauman, K. E., Harris, K. M., Jones, J., ... \& Ireland, M. (1997). Protecting adolescents from harm: findings from the National Longitudinal Study on Adolescent Health. Jama, 278(10), 823-832.

Shehu, A. U. \& Idris, S. H. (2008). Marijuana smoking among secondary school students in Zaria, Nigeria: Factors responsible and effects on academic performance. Annals of African Medicine, 7(4), 175-179.

Usen, I. (2012). Community Theatre in Nigeria: Progress, Challenges and the Way Forward. Kiabara: Journal of Humanities, 18(1).

Van Erven, E. (2002). Community theatre: Global perspectives. Routledge.

Wiley, L. \& Feiner, D. (2001). Making a Scene: Representational Authority and a CommunityCentered Process of Script Development. In Haedicke, C. S. \& Nellhaus, T. (Eds.), Performing Democracy: International Perspectives on Urban Community-Based 
East African Journal of Interdisciplinary Studies, Volume 2, Issue 1, 2020

Article DOI: https://doi.org/10.37284/eajis.2.1.155

Performance. United States of America: The University of Michigan Press. 